\title{
Vegetation Structure in Shahbazgari, District Mardan
}

\author{
Musharaf Khan*¹, Farrukh Hussain ${ }^{2}$, Shahana Musharaf ${ }^{3}$ \\ ${ }^{1}$ Department of Biological Sciences, Federal Government College Mardan Cantt, Pakistan. \\ ${ }^{2}$ Department of Biotechnology, Sarhad University of Science and Information Technology \\ Peshawar, Pakistan. \\ ${ }^{3}$ Department of Chemistry, Government Girls Degree College, Sheikh Maltoon, Mardan, Pakistan. \\ Email address*: k.musharaf@gmail.com
}

Keywords: Quadrat method; community structure; vegetation; soil

\begin{abstract}
The present work was made to investigate the vegetation structure of shrubs and herbs in research area. Total 48 plant species consisting of 7 shrubs and 41 herbs constructing CenchrusZizyphus-Saccharum community from 9 sites in which 9 communities i.e. Fumaria-RumexXanthium community, Cynodon-Solanum-Sonchus community, Cynodon-Sorghum-Alhagi community, Ajuga- Malvastrum-Calotropis community, Cynodon -Convolvulus-Cyperus community, Ajuga-Saccharum-Chenopodium community, Alhagi-Rumex-Euphorbia community, Saccharum-Cannabis-Xanthium community and Achyranthus-Ajuga-Euphorbia community were found. The contribution of total important values by shrubs was 43.78 and 256.2 by herbs. The soil of the area had better calcium carbonate in the range of $(11.72-12.99 \%)$, with soil $\mathrm{pH}(6.45-$ 8.11). The EC was found in the range of $\left(0.13-0.22 \mathrm{dS} \mathrm{m}^{-1}\right)$. The concentrations of $\mathrm{P}$ and $\mathrm{K}$ content were found in the range of (3.54-3.92 mg Kg${ }^{-1}$ ) and (111.21-127.14 mg Kg$\left.{ }^{-1}\right)$. These results highlight the constant need for long-term ground-based conservation monitoring in combination with satellite-based monitoring of changes in vegetation cover.
\end{abstract}

\section{INTRODUCTION}

Vegetation community structure shows the plant species diversity in an area. The vegetation of earth is modified to the insignificant conditions occurring with thin populations. The researchers $[1,2,3]$ have studied different aspects of vegetation structure and distribution patterns in different parts of Pakistan. Phytosociology of Central European phyto-sociology has been developing since the early 20th century by [4]. The author [5] stated that the community as a whole usually exhibits seasonal fluctuations, and its structure and composition are strongly influenced by the quantity of species. The authors [6] stated that the Phytosociology is an invaluable method for vegetation survey. The authors [7] research out the phytosociology of roadside communities and as a result 85 species were observed. The authors [8] reported 11 plants community during summer in Tehsil Takht-E-Nasrati Hills, District Karak, Pakistan. The author [9] studied the Maturity dynamism of plant life and pointed out that the species frequency was changed with the change of season and altitude. The community structure and distribution patterns of research area and their hills have not been given due attention till the date by the plant ecologists, and hence poorly understood [10, 11, $12,13]$. The distribution and community structure of vegetation is managed by unfavorable edaphic and climatic factors; mainly by rainfall, temperature and redistribution of water. The soil is a complex structure, consisting of different raw material, gases, organic and inorganic molecules in different structure with different properties and characteristics. Water is present in the pore of soil particles which dissolve the organic and inorganic molecules for use of land plants. The quantity of these molecules affects the structural and physical condition of the soil. These molecules play a key role in stopping waste elements in a definite soil due to the presences of highly reactive charged particles and the positively charged surfaces serve as anion exchange media for negatively charged constituents. Soil is the upper surface of the earth which is produced from the parent material through environmental factors and chemical reaction of different molecules consequently provide 
the natural medium for the plant growth and differs from parent material in physical, morphological, chemical and biological properties and characteristics. The investigated area low altitude grazing hills are very important being a wild life habitat, water catchment and a livelihood source for nomadic and transhumant inhabitants. The Shahbaz Garhi lies from $34^{\circ} 23^{\prime \prime N} 72^{\circ} 17^{\prime \prime E}$. The elevation of the valley is 1000 to $2056 \mathrm{~m}$ above sea level. The total area of the valley is 5 kilometers sq. the research area is situated on the junction of three ancient routes i.e. Kabul to Pushkalavati, Swat through Buner and Taxila through Hund on the bank of lndus River. The town was once a thriving Buddhisy city surrounded by monasteries and stupas [11]. The research area is severely despoiled due to nomadic and sedentary live-stock overgrazing. Due to huge population increases and increasing urbanization practices, existing reserve forests and grazing lands are overburdened with community rights making it impossible to reduce the grazing pressure [12]. Grazing practices are one of the important determinants of vegetation circulation model and having most noticeable impact on the floral biodiversity of an area [13].

\section{MATERIALS AND METHODS}

The phytosociological expeditions were carried out in 2013 -2014. Quadrat method was used to study and analyse the vegetation dynamic as well as to collect the primary data for statistical analyses. A total of 9 sites were laid in the study area. 10 Quadrats were laid in each selected sites having best representation of floral biodiversity and geographic extent of the area.

\subsection{VEGETATION ATTRIBUTES}

Vegetation attributes including frequency, density and cover were recorded. The importance value of each species was compiled adding relative density (RD), relative frequency (RF) and relative cover (RC) following [14, 24].

\subsection{COMMUNITY NAMED}

On the basis of the highest importance values of the first three dominant species from each layer, the communities were established and named. Plants from the premises of sampling points as well as isolated vegetation patches were also collected to record maximum number of species and their distribution patterns. Collected samples were pressed, dried and transported to herbarium of Federal Government College Mardan Cantt, Khyber Pakhtunkhawa, Pakistan, where they were identified and classified following $[3,15,16]$.

\subsection{EDAPHOLOGY}

Two kg soil sample was collected from nine sites of research area up to $15 \mathrm{~cm}$ depending upon the area situation. Collection of soil was taken from outer periphery of plants canopy or at the centre of plants with the help of soil auger. Soil of each site mixed to make a composite sample. After dryness and passing through $2 \mathrm{~mm}$ sieve, samples were stored for further experiment. There were 5 replicates from each site. These were analyzed for different chemical and physical parameters including soil texture, organic matter, lime contents, $\mathrm{pH}, \mathrm{EC}$, phosphorus and potassium as following standard methods $[14,17,18]$.

\section{RESULTS}

In investigated area collectively 48 plant species consisting of 7 shrubs and 41 herbs constructing Cenchrus-Zizyphus-Saccharum community from 9 sites in which 9 communities i.e. Fumaria-Rumex-Xanthium community, Cynodon-Solanum-Sonchus community, CynodonSorghum-Alhagi community, Ajuga-Malvastrum-Calotropis community, Cynodon-ConvolvulusCyperus community, Ajuga-Saccharum-Chenopodium community, Alhagi-Rumex-Euphorbia community, Saccharum-Cannabis-Xanthium community and Achyranthus-Ajuga-Euphorbia community were found. Fumaria-Rumex-Xanthium community was composed of 14 species at site A. The Importance value contributed by three dominants species i.e. Fumaria indica, Rumex dentatus and Xanthium strumarium was 82.59. The associated species in herbaceous stratum included Carthamus oxycantha (IV = 24.59), Cymbopogon distans (IV=22.79), Chrozophora oblique $(\mathrm{IV}=21.73)$ and Cynodon dactylon $\quad(\mathrm{IV}=21.23)$ (Table 1$)$. The community preferred to 
grow on high percentage of clay (58\%) and low amount of silt (27\%) and sand (15\%) particles. The soil of the community had better calcium carbonate $(12.33 \%)$ with alkaline soil $\mathrm{pH}(7.85)$. The concentrations of $\mathrm{P}$ and $\mathrm{K}$ content were found in the range of 3.55 and $113.21 \mathrm{mg} \mathrm{Kg}-1$. The community preferred EC in the range of $0.13 \mathrm{dS} \mathrm{m}-1$. The soil texture was found clay (Figures 1-4). Cynodon-Solanum-Sonchus community was present at Site B. This community was supported by 13 plant species in which consist of 3 shrubs and 10 herb species. The dominant plant species were Cynodon dactylon (IV = 32.5) Solanum surattense (IV = 26.41) and Sonchus asper $(\mathrm{IV}=26.31)$, Calotropis procera (23.47) and Cyperus scarlosus (IV = 22.22) and Saccharum spontaneum (IV = 22.12) (Table 1). The community preferred to grow on high percentage of clay $(66 \%)$ and low amount of sand $(18 \%)$ and silt $(16 \%)$ particles. The soil of the community had better calcium carbonate (12.35\%) with soil $\mathrm{pH}(6.45)$. The concentrations of $\mathrm{P}$ and $\mathrm{K}$ content were found in the range of 3.57 and $115.71 \mathrm{mg} \mathrm{Kg}-1$. The community preferred $\mathrm{EC}$ in the range of $0.2 \mathrm{dS} \mathrm{m}-1$ (Figures 1-4). Cynodon-Sorghum-Alhagi community was established at site $\mathrm{C}$ and is dominated by Cynodon dactylon (IV $=26.87)$, Sorghum halepense $(\mathrm{IV}=25.85)$ and Alhagi maurorum $(\mathrm{IV}=$ 24.23). The associated species included Convolvulus arvensis $(\mathrm{IV}=20.58)$ and Cyperus scarlosus $(\mathrm{IV}=18.66)$ (Table 1$)$. The community preferred to grow on high percentage of clay $(59 \%)$ followed by silt $(22 \%)$ and sand $(19 \%)$ particles. The soil of the community had lime contents $(11.72 \%)$ and $\mathrm{EC}(0.17 \mathrm{dS} \mathrm{m}-1)$ with soil $\mathrm{pH}(6.95)$. The concentrations of $\mathrm{P}$ and $\mathrm{K}$ content were initiated in the range of 3.59 and $117.47 \mathrm{mg} \mathrm{Kg}-1$, respectively. The soil texture was found to be clay (Figures 1-4). AMC community was composed of 23 species comprising 4 shrubs and 19 herb species at site D. The Importance value contributed by three dominants species i.e. Ajuga bractiosa, Malvastrum coromandelianum and Calotropis procera was 56.7 while total importance value of 243.3 was provided by the remaining species. Associated species included Cannabis sativa $(\mathrm{IV}=16.9)$, Cassia occidentalis (IV $=16.9)$ and Cymbopogon distans $(\mathrm{IV}=15.4)$ (Table 1). The community preferred to grow on high percentage of clay $(61 \%)$ and low amount of sand $(23 \%)$ and silt (16\%) particles. The soil of the community had better calcium carbonate $(12.36 \%)$ with soil $\mathrm{pH}$ (7.11). The concentrations of $\mathrm{P}$ and $\mathrm{K}$ content were found in the range of 3.54 and $122.41 \mathrm{mg} \mathrm{Kg}-1$. The community preferred EC in the range of $0.19 \mathrm{dS} \mathrm{m}-1$ (Figures 1-4). Cynodon-ConvolvulusCyperus community was established at site $\mathrm{E}$ and composed of 20 species. This community was dominated by Cynodon dactylon (IV = 25.95), Convolvulus arvensis (IV = 23.44) and Cyperus scarlosus (IV=20.83) (Table 1). The community preferred to grow on high percentage of clay $(57 \%)$ followed by silt $(22 \%)$ and sand $(21 \%)$ particles. The soil of the community had lime contents $(12.45 \%)$ and EC $(0.22 \mathrm{dS} \mathrm{m}-1)$ with soil $\mathrm{pH}(6.84)$. The concentrations of $\mathrm{P}$ and $\mathrm{K}$ content were initiated in the range of 3.67 and $119.23 \mathrm{mg} \mathrm{Kg}-1$, respectively. The soil texture was found to be clay (Figures 1-4). Ajuga-Saccharum-Chenopodium community was developed at site F and was dominated by Ajuga bractiosa (IV = 26.05), Saccharum spontaneum $(\mathrm{IV}=25.09)$ in tree strata and Chenopodium album (IV = 22.63). This community was supported by 16 plant species (Table 1$)$. The community preferred to grow on high percentage of clay $(56 \%)$ followed by silt $(22 \%)$ and sand $(22 \%)$ particles. The soil of the community had lime contents $(12.26 \%)$ and EC $(0.17 \mathrm{dS} \mathrm{m}-1)$ with soil $\mathrm{pH}$ (6.94). The concentrations of $\mathrm{P}$ and $\mathrm{K}$ content were initiated in the range of 3.62 and $124.36 \mathrm{mg} \mathrm{Kg}-1$, respectively. The soil texture was found to be clay (Figures 1-4). ARE community was developed at site $G$ and composed of 19 species. There were 3 shrubs and 16 herb species. Dominant plant species on the basis of important values were Alhagi maurorum (IV $=25)$, Rumex dentatus (IV = 21.6) and Euphorbia hirta (IV = 21.4) (Table 1). The community preferred to grow on high percentage of clay $(62 \%)$ and low amount of sand $(20 \%)$ and silt $(18 \%)$ particles. The soil of the community had better calcium carbonate $(12.41 \%)$ with soil $\mathrm{pH}(7.23)$. The concentrations of $\mathrm{P}$ and $\mathrm{K}$ content were found in the range of 3.63 and $127.14 \mathrm{mg} \mathrm{Kg}-1$. The community preferred EC in the range of $0.18 \mathrm{dS} \mathrm{m}-1$ (Figures 1-4). Saccharum-Cannabis-Xanthium community was established at site $\mathrm{H}$ was composed of 24 species. There were 3 shrubs and 21 herb species. The Importance value contributed by three dominants species i.e. Saccharum spontaneum, Cannabis sativa and Xanthium strumarium was 55.95 (Table 1). The community preferred to grow on high percentage of clay $(68 \%)$ and low amount of sand (17\%) and silt (15\%) particles. The soil of the 
community had better calcium carbonate $(12.99 \%)$ with soil $\mathrm{pH}(8.11)$. The concentrations of $\mathrm{P}$ and $\mathrm{K}$ content were found in the range of 3.71 and $111.21 \mathrm{mg} \mathrm{Kg-1}$. The community preferred EC in the range of $0.19 \mathrm{dS} \mathrm{m-1} \mathrm{(Figures} \mathrm{1-4).} \mathrm{Achyranthus-Ajuga-Euphorbia} \mathrm{community} \mathrm{was} \mathrm{composed} \mathrm{of}$ 21 species at site I. Dominant plant species on the basis of important values were Achyranthus aspera (IV = 25), Ajuga bractiosa (IV = 24.1) and Euphorbia helioscopia (IV = 21.1) (Table 1). The community preferred to grow on high percentage of clay $(53 \%)$ followed by sand (24\%) and silt $(23 \%)$ particles. The soil of the community had lime contents $(12.33 \%)$ and EC $(0.21 \mathrm{dS} \mathrm{m}-1)$ with soil $\mathrm{pH}$ (6.94). The concentrations of $\mathrm{P}$ and $\mathrm{K}$ content were initiated in the range of 3.92 and $124.23 \mathrm{mg} \mathrm{Kg}-1$, respectively. The soil texture was found to be clay (Figures 1-4).

Table 1. Total Important Value of communities present in nine sites of Shahbaz Gari,

\begin{tabular}{|c|c|c|c|c|c|c|c|c|c|c|}
\hline Species Name & FRX & CSS & CSA & $\mathrm{AMC}$ & $\mathrm{CCC}$ & ASC & ARE & SCX & AAE & TIV \\
\hline Achyranthus aspera L. & - & 19.63 & 16.99 & 13.8 & 11.06 & - & - & 12.04 & 25 & 10.9 \\
\hline Ajuga bractiosa Wall. Benth. & - & - & - & 20.7 & - & 26.05 & - & - & 24.1 & 7.87 \\
\hline Ajuga parviflora Benth & - & - & - & 15.3 & 13.68 & - & 9.5 & - & 14.7 & 5.91 \\
\hline Alhagi maurorum Medic. & 16.56 & 22.02 & 24.23 & 12 & - & 20.06 & 25 & 11.86 & 10.1 & 15.8 \\
\hline Amaranthus viridis L. & - & - & - & - & 12.15 & - & - & 11.48 & - & 2.63 \\
\hline $\begin{array}{l}\text { Boerhaavia procumbens } \\
\text { Banks ex Roxb. }\end{array}$ & - & - & - & 12.7 & - & 15.06 & - & - & - & 3.08 \\
\hline $\begin{array}{l}\text { Calotropis procera (Wight.) } \\
\text { Ali. }\end{array}$ & - & 23.47 & 16.86 & 17.8 & 13.82 & - & 10.6 & - & - & 9.17 \\
\hline Cannabis sativa L. & 16.92 & - & - & 16.9 & - & 12.41 & 16.7 & 18.63 & 10.7 & 10.3 \\
\hline $\begin{array}{l}\text { Capsella bursa-pestoris } \\
\text { Medic. }\end{array}$ & - & - & - & - & 12.88 & - & - & 15.17 & 16.5 & 4.95 \\
\hline $\begin{array}{l}\text { Carthamus oxycantha } \mathrm{M} . \\
\text { Bieb. }\end{array}$ & 24.59 & - & - & - & - & 20.14 & - & - & - & 4.97 \\
\hline Cassia occidentalis L. & 16.33 & - & - & 16.9 & 16.01 & - & 9.5 & - & - & 6.53 \\
\hline Cenchrus ciliaris L. & - & - & - & - & - & 18.84 & 13.4 & 7.46 & - & 4.41 \\
\hline Centaurea calcitrapa L. & - & 19.96 & - & - & 14.74 & - & - & 6.9 & 13.7 & 6.14 \\
\hline Chenopodium album L. & - & - & - & 13.1 & - & 22.63 & - & - & 13.9 & 5.51 \\
\hline Chenopodium murale L. & - & - & - & - & 12.32 & - & 13.1 & - & - & 2.82 \\
\hline $\begin{array}{l}\text { Chrozophora oblique (Vahl) } \\
\text { A. Juss. }\end{array}$ & 21.73 & - & - & 8.86 & - & - & 15.4 & 12.6 & - & 6.51 \\
\hline Convolvulus arvensis L. & - & - & 20.58 & - & 23.44 & - & - & 13.49 & - & 6.39 \\
\hline $\begin{array}{l}\text { Cymbopogon distans (Nees ex } \\
\text { Steud.)Watson. }\end{array}$ & 22.79 & 20.77 & - & 15.4 & - & - & - & - & 9.5 & 7.61 \\
\hline Cynodon dactylon $\quad$ L. Pers. & 21.23 & 32.5 & 26.87 & - & 25.95 & - & 14.4 & - & 13 & 14.9 \\
\hline Cyperus rotundus L. & - & - & - & 13.5 & - & - & - & 14.12 & - & 3.07 \\
\hline Cyperus scarlosus R.Br. & 17.97 & 22.22 & 18.66 & - & 20.83 & - & 17.8 & 15.19 & - & 12.5 \\
\hline Datura metel L. & - & - & - & 7.41 & - & - & - & - & - & 0.82 \\
\hline $\begin{array}{l}\text { Euphorbia helioscopia } \\
\text { Mewski. }\end{array}$ & 17.74 & - & 14.94 & - & 9.65 & - & - & - & 21.1 & 7.05 \\
\hline Euphorbia hirta L. & - & 22.1 & - & 6.62 & - & 20.67 & 21.4 & 9.7 & 17.4 & 10.9 \\
\hline Euphorbia prostrata L. & - & - & - & - & 8.82 & - & - & 16.32 & - & 2.79 \\
\hline $\begin{array}{l}\text { Fumaria indica (Hausskn) } \\
\text { Pugsley. }\end{array}$ & 28.12 & - & - & - & - & 15.39 & 15.6 & - & - & 6.57 \\
\hline Gallium aparine $\mathrm{L}$. & - & - & - & 10.9 & 15.03 & - & - & - & - & 2.88 \\
\hline Heliotropium europaeum L. & 20.68 & - & - & - & - & - & - & 15.19 & 13 & 5.43 \\
\hline Launea procumbens Roxb. & - & 24.24 & - & 16.5 & 17.44 & - & 15.8 & 13.73 & 13.1 & 11.2 \\
\hline Malva neglecta Wallr. & - & - & 17.32 & - & - & 18.29 & - & - & - & 3.96 \\
\hline $\begin{array}{l}\text { Malvastrum coromandelianum } \\
\text { (L.) Garcke. }\end{array}$ & - & - & - & 18.2 & 18.36 & - & - & - & - & 4.06 \\
\hline
\end{tabular}




\begin{tabular}{|c|c|c|c|c|c|c|c|c|c|c|}
\hline Oxalis corniculata L. & - & - & 17.19 & - & - & - & 15.6 & 12.43 & - & 5.02 \\
\hline Parthenium hysterophorus L. & - & - & - & - & 11 & - & - & 9.1 & 8.1 & 3.13 \\
\hline Riccinis communis L. & - & - & - & 12.1 & - & - & - & - & 16.9 & 3.22 \\
\hline Rumex dentatus L. & 27.57 & - & - & - & - & - & 21.6 & - & - & 5.46 \\
\hline Saccharum spontaneum L. & - & 22.12 & 15.51 & - & - & 25.09 & 15.5 & 20.58 & - & 11 \\
\hline $\begin{array}{l}\text { Silybum marianum (L.) } \\
\text { Gaertn. }\end{array}$ & - & - & - & 9.88 & - & - & - & 9.2 & - & 2.12 \\
\hline Solanum nigrum L. & - & - & 17.8 & - & - & 16.11 & - & - & 11.8 & 5.08 \\
\hline Solanum surattense Burm.f. & - & 26.4 & 15.27 & 6.43 & - & - & 18 & - & 13 & 8.79 \\
\hline Sonchus arvensis L. & - & - & - & - & - & 20.06 & 14.3 & 11.66 & - & 5.11 \\
\hline Sonchus asper (L.) Hill. & - & 26.31 & 19.2 & 13.1 & - & - & - & 10.04 & - & 7.63 \\
\hline Sonchus auriculata L. & 20.87 & - & - & - & - & - & - & - & - & 2.32 \\
\hline $\begin{array}{l}\text { Sorghum halepense (L.) } \\
\text { Persoon. }\end{array}$ & - & - & 25.85 & 11.2 & 19.97 & - & 16.8 & - & 16.9 & 10.1 \\
\hline Stellaria media (L.) Cry. & - & - & - & - & - & 19.79 & - & 9.4 & 7 & 4.02 \\
\hline Taraxacum officinale Weber. & - & - & 17.51 & 10.7 & 12.76 & - & - & 6.97 & - & 5.33 \\
\hline Tribulus terrestris L. & - & 18.26 & - & - & - & 16.99 & - & - & - & 3.92 \\
\hline Withania somnifera (L) Dunal. & - & - & 15.22 & - & 10.09 & - & - & - & - & 2.81 \\
\hline Xanthium strumarium L. & 26.9 & - & - & - & - & 12.42 & - & 16.74 & 10.5 & 7.4 \\
\hline
\end{tabular}

\section{DISCUSSION}

The area of Shahbaz Gari is very important being a wild life habitat, water catchment and a livelihood source for nomadic and transhumant inhabitants. The distribution and community structure of plant life is governed by adverse edaphic and climatic factors; mainly by rainfall and redistribution of water that decrease with the increase in altitude. Temperature is also one of the most important limiting factors controlling the distribution and community structure of vegetation in research area. The research area is characterized by scanty rainfall, high ultraviolet (UV) radiation, high wind velocity, blizzards and high temperature. The plants of this zone show an adaptation to these conditions and are generally dwarfed, stunted, wooly or spiny, and develop a mosaic patch of different forms (Figures 5,6). They possess an early growth initiation with a tiny vegetative period ranging from several days to a few months. The hilly area is used for grazing throughout the year. The hilly areas are severely degraded due to nomadic and sedentary livestock overgrazing. Due to huge population increases and frighteningly increasing urbanization practices, existing reserve forests and grazing lands are overburdened with community rights making it impossible to reduce the grazing pressure (Figure 7).

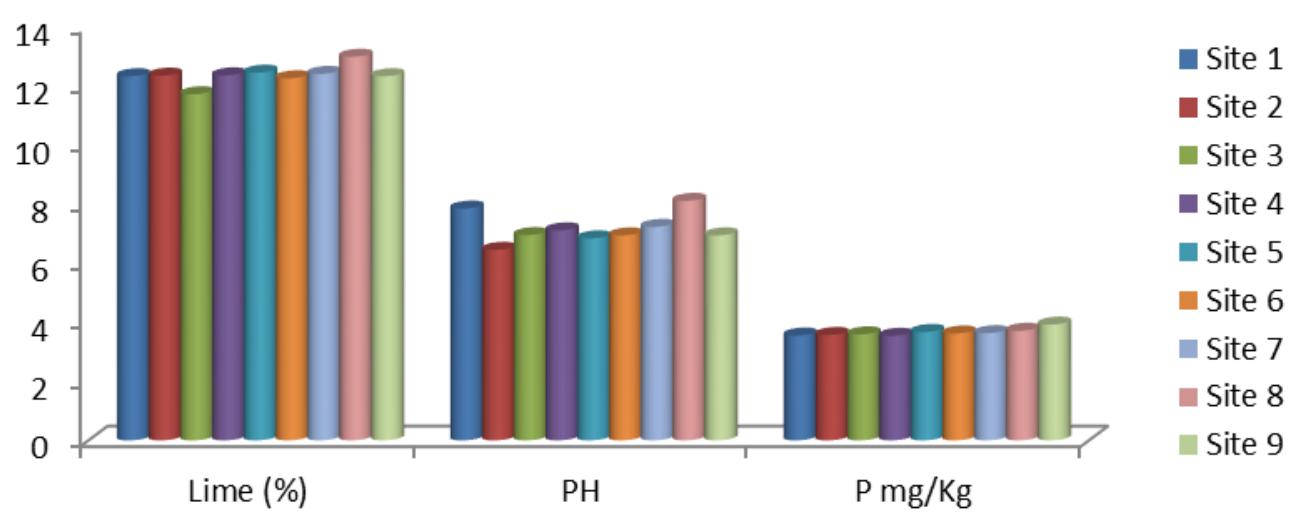

Figure 1. Value of Lime (\%), PH and P mg/kg in different site of shahbaz Gari, District Mardan. 


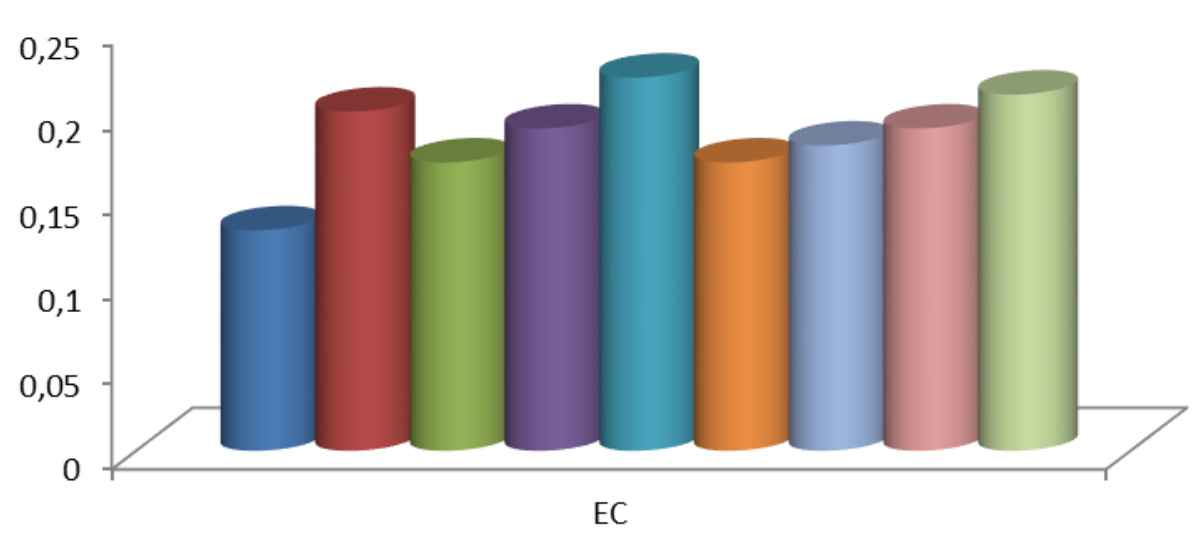

a Site 1

site 2

Site 3

- Site 4

- Site 5

- Site 6

Site 7

Site 8

Site 9

Figure 2. Value of EC in different site of shahbaz Gari, District Mardan.

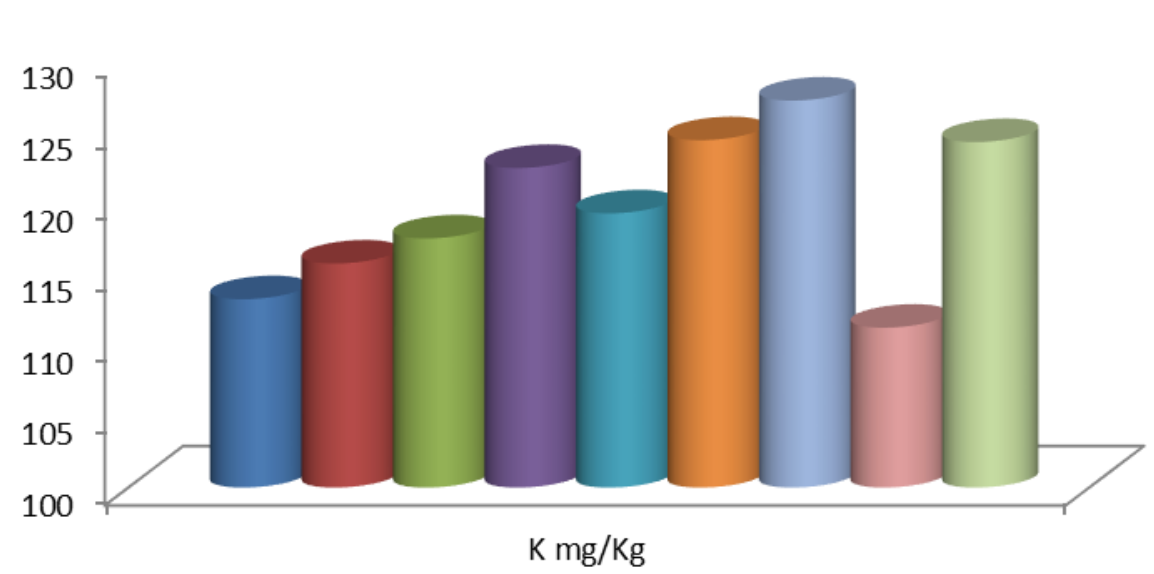

- Site 1

- Site 2

- Site 3

- Site 4

- Site 5

- Site 6

- Site 7

- Site 8

Site 9

Figure 3. Value of $\mathrm{K} \mathrm{mg} / \mathrm{Kg}$ in different site of shahbaz Gari, District Mardan.

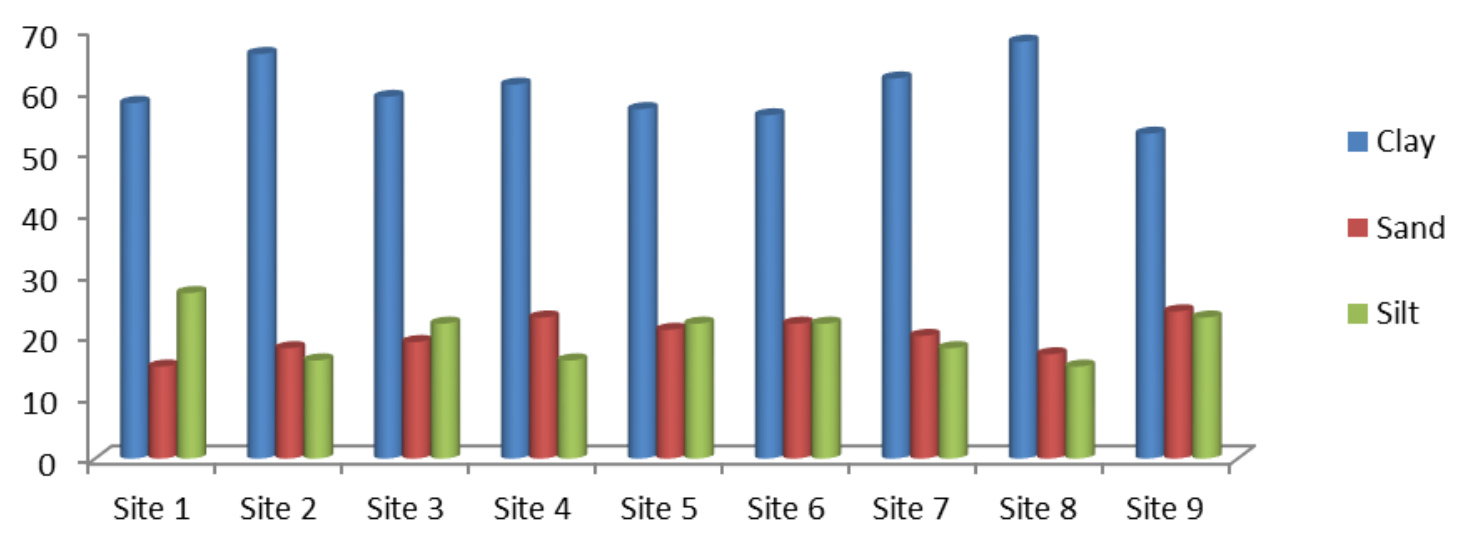

Figure 4. Soil particles percentage in different sites of shahbaz Gari, District Mardan.

Grazing practices are one of the important determinants of vegetation distribution patterns and having most obvious impact on the floral biodiversity of an area (Figure 8). In the present study, an effort has been made to investigate and analyse correlation of vegetative attributes of herbs and shrubs. Due to huge population increases and frighteningly increasing urbanization practices, existing reserve forests and grazing lands are overburdened with community rights making it impossible to reduce the grazing pressure [19, 20, 21, 22, 29]. Grazing practices are one of the important determinants of vegetation distribution patterns and having most obvious impact on the floral biodiversity of an area [22, 23). 


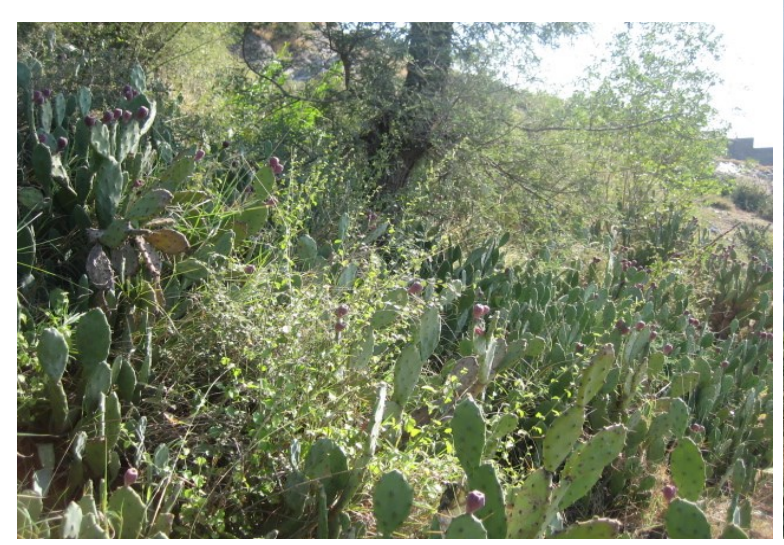

Figure 5. Spiny vegetation in research area.

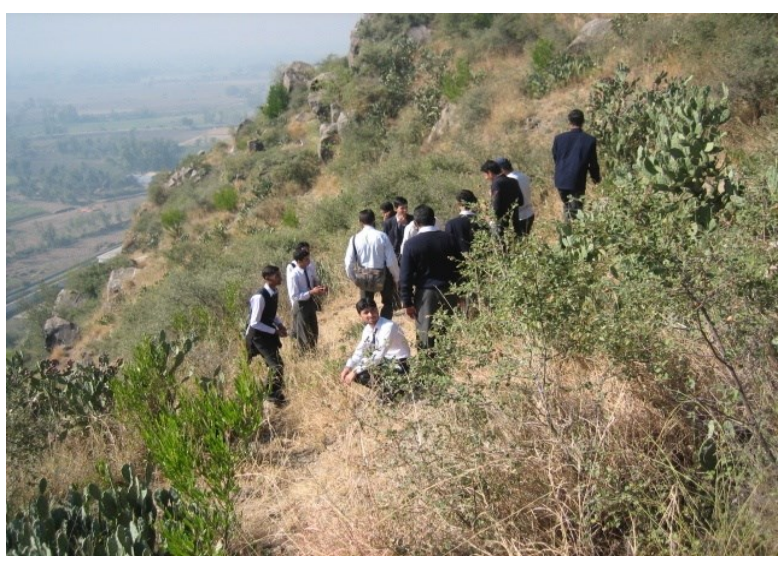

Figure 6. Spiny vegetation in research area.

The investigated area comprised of 48 species in 9 communities. The environmental factors, habitat and different plant life determined communities' structure. Plants communities are useful in classification, naming and identification of vegetation structure. The author [24] stated that plant community structure interpret and analyze the plant life at diverse revelation and offer immediate information regarding plant life and are origin for deduction of future alteration. The author [8, 21, 22] evaluated the plant life reaction to ecological situation of open woodlands along an altitudinal and animal palatability preference. The factors which influenced plant life structure are unplanted settlements, overgrazing, erosion, land sliding, habitat destruction, poverty and anthropogenic activities. In research area, 9 plant communities were identified at various parts at different altitudes. The diverse plant communities documented in diverse seasons reflected different remains as recognized by [25]. Soil is essential that has continued life on earth and it also helps the plants' growth that increased the competition of grazing animals and human. According to author [26, 22] stated that the distinctive habitation altered due to increasing human transportation and population. Other progression results into increased the expected attack of organism has been happening the world over. Plant life changed the physical and chemical properties of soil. It improves the soil infiltrations, structure and prevents erosion. The authors $[8,27,28]$, described that the resources of soil is limited and its physical and chemical properties are restricted mostly by humus and clay. Several research works dealing with different features of plant life from diverse parts of the state have been taken out form time to time $[16,19,21,22,29]$. The investigated area presents a limited number of animal and plant species. Plant growth somewhat indirectly manipulated through soil structure. It also effects the seedling growth which is very sensitive to physical condition of soil texture. The rigid compacted layer slows down the growth of the seedling for root cannot penetrate easily in such soil.

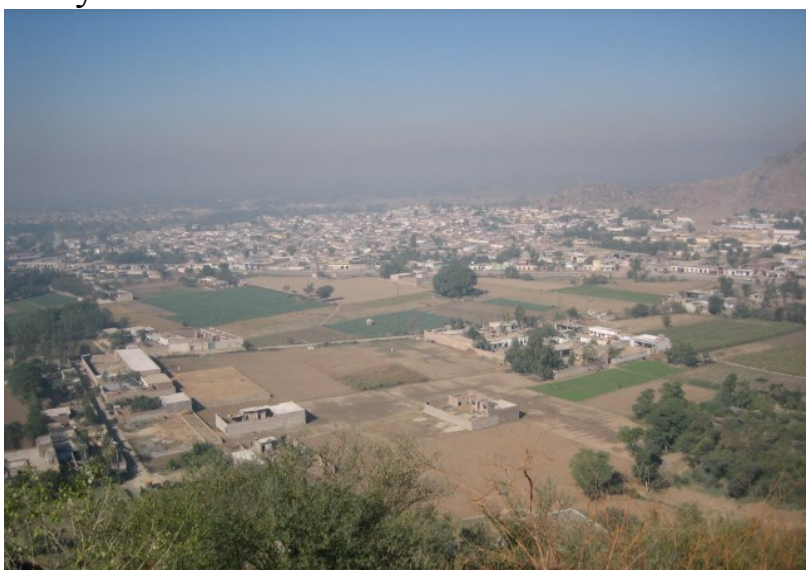

Figure 7. Population increase with time in research area.

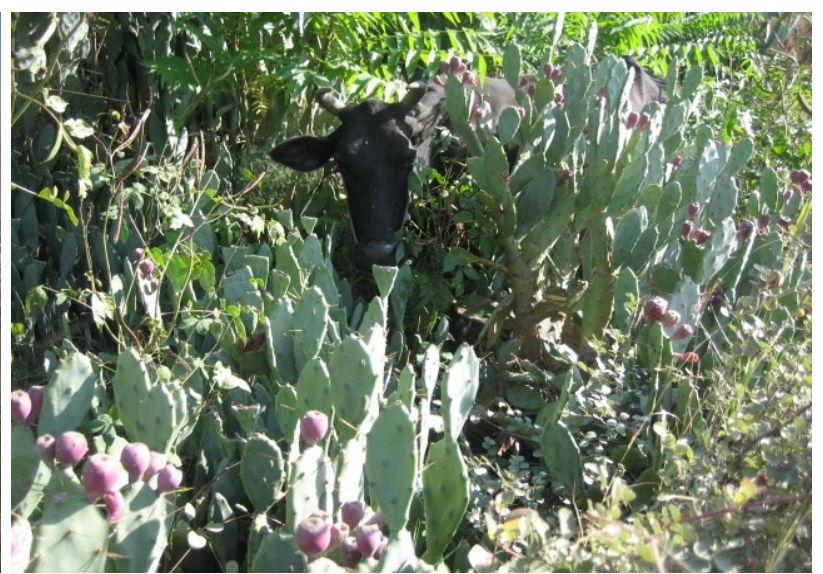

Figure 8. Grazing of plant species by cow.

\section{CONCLUSION}

The initial objective of this work was to show the correlation between plant species in the form of vegetation community structure in semi-arid environments. Although variations in the 
relative proportions of herb and shrubs cover are likely to change the composite reflectance. Therefore, the relationship cannot be overturned and used to estimate variations in vegetation structure. Grazing practices need to be limited and monitored along with creating the awareness among the native about conservation and sustainable management of grasslands. Fenced vegetation plots should be designed at regular intervals to act as seed banks in whole area.

\section{COMPETING INTERESTS}

The authors declare that they have no competing interests.

\section{ACKNOWLEDGEMENT}

The paper is a practical work of under graduate students of Biological Sciences Department, Federal Government College Mardan Cantt. Authors are grateful to the local people of area who have revealed the precious information about plant species and assistance. We cannot forget all our friends for all support they accorded us during the period we carried out this study.

\section{References}

[1] Vigne GT. Travelsin Kashmir, Ladakh,I scardo, theC ountries Adjoining the Mountain-courseo $f$ the Indus, and the Himalaya, North of the Panjab. 2 Vols. H. Colburn, London. 1842.

[2] Duthie JF. Catalogue of the Plants of Kumaon and Adjacent portions of Garhwal and Tibet Based on the Collections made by Strachey and Winterbottom during the Years 1846-1849, Lovell Reeve and Co, Ltd, London. 1906.

[3] Stewart RR. The Flora of Deosai plains. Pak. J. For., 1961. 11: 225-295.

[4] Braun-Blanquet, J. Pflanzensoziologie. Grundzüge der Vegetationskunde. Springer, Berlin. 1928.

[5] Kershaw RA. Quantitative and Dynamic Plant Ecology. London: Edward Arnold. 1973.

[6] Rieley J, Page S. Ecology of plant communities: A phytosociological account of the British Vegetation. John Wiley and sons, Inc., New York. 1990. p. 178.

[7] Ray J. G, George J. Phytosociology of roadside communities to identify ecological potentials of tolerant species. Journal of Ecology and the Natural Environment. 2009. 1(5): 184-190.

[8] Khan M, Hussain F. Vegetation structure in summer of Tehsil Takht-e- Nasrati plains, district Karak, Pakistan. African Journal of Plant Science. 2013. 7(8): 339-350.

[9] Khan M, Hussain F, Musharaf S Maturity dynamism of plant life in Tehsil Takht-e-Nasrati, District Karak, Pakistan. International Journal of Bioscience. 2012. 2(3):67-74.

[10] Khan M, Hussain F, Faridullah, Musharaf S. Ordination and Classification of Vegetation in Semi Arid Area of Pakistan. Global Journal of Science Frontier Research. 2014. 14 (2):11-19.

[11] Khan M, Hussain F, Musharaf S. Floristic Composition and Ecological Characteristics of Shahbaz Garhi, District Mardan, Pakistan. Global Journal of Science Frontier Research. 2014.14 (1): 7-17.

[12] Khan M, Hussain F, Faridullah, Musharaf S. Classification of Plant Species in Tehsil Katlang, District Mardan, Khyber Pakhtunkhawa, Pakistan. Medicinal Plant Research. 2014. 4(3):18-29. doi: 10.5376/mpr.2014.04.0003

[13] Khan M, Musharaf S. Conservation Position of Plant Species in Tehsil Katlang, District Mardan, Pakistan. Medicinal Plant Research. 2014. 4(7): 55-60. (doi: 10.5376/mpr.2014.04. 0007.

[14] Hussain F. Field and Laboratory Manual of Plant Ecology. University Grants Commission, Islamabad. 1989. 
[15] Nasir E, Ali SI. Flora of Pakistan. Fascicles. Karachi. Pakistan. 1970-1994.

[16] Stewart RR. History and exploration of plants in Pakistan and adjoining Areas. (Nasir, E, S.I. Ali, eds.) Pan Graphics, Islamabad, Pakistan. 1982.

[17] Bouyoucos GJ. Hydrometer method improved for making particle-size analysis of soils. Agron. Journal. 1962. 53,464-465.

[18] Jackson M A. Soil Chemical Analysis. Constable and Co, Ltd., London. 1992.

[19] Khan M, Hussain F. Palatability and animal preferences of plants in Tehsil Takht-e-Nasrati, District Karak, Pakistan. African Journal of Agricultural Research. 2012. 7(44): 5858-5872. DOI: 10.5897/AJAR12.2095

[20] Khan M, Hussain F, Musharaf S. Biodiversity of plant species in Tehsil Takht-e-Nasrati, Pakistan. International Journal of Biodiversity and Conservation, 2013. 5(1): 39-46. DOI: 10.5897/IJBC12.130.

[21] Khan M, Hussain F. Plants Community Composition and Dynamism During Summer in Tehsil Takht-E-Nasrati Hills, District Karak, Pakistan. Global Journal of Science Frontier Research Biological Science. 2013. 13(2): 21-30.

[22] Khan M. Dimension and composition of plant life in Tehsil Takht-e-Nasrati, District Karak, Khyber Pakhtunkhawa, Pakistan. PhD. Thesis (Plant Ecology), Department of Botany, University of Peshawar, Peshawar, Pakistan. 2013.

[23] Khan M, Hussain F, Musharaf S, Haider AS, Imdadullah. Soil examination and Measurement of Tehsil Takht-e-Nasrati, Pakistan. International Journal of Bioscience. 2012. 2(3):58-66.

[24] Muller-Dumbois D, Ellenberg H. Aims and Methods of Vegetation Ecology. John Wiley and Sons, N. Yark. 1974. pp. 547.

[25] Champion HG, Seth SK, Khattak GM. Forest Types of Pakistan. Pakistan Forest Institute, Peshawar. 1965.

[26] Turner WR, Nakamura T, Dinetti M. Global urbanization and separation of humans from nature. Bio Science. 2004. 54: 585-590.

[27] Buckman HO, Brady NC. The nature and properties of soils. Eurasia Publishing House (Pvt) Ltd. New Delhi. 1967.

[28] Khan M, Musharaf S. Ethnomedicinal and Conservation Status of Plant Species in Tehsil Takht Bhai, District Mardan, Pakistan, International Letters of Natural Sciences. 2015. 37: 1829.

[29] Khan M, Abdurehman, Hussain F, Shinwari ZK, Musharaf S. Ethnomedicinal and conservation status of herbs in Tehsil Banda Daud Shah, District Karak, Pakistan. International Letters of Natural Sciences. 2014. 15(2): 190-197. 